\title{
ECONOMIC ASPECTS OF AIRSPACE CONTROL AND PROTECTION ${ }^{\star * * * *}$
}

Airspace control and protection is extremely significant task for every state from security, political, economic and other points of view. However, airspace control requires engagement of technology and people. This, in turn, generates certain costs. This paper presents the research results of long-term financial sustainability of the performance of airspace control and protection on the example of the Republic of Serbia. Cost analysis of this task was realized on the basis of information available from open sources, and the KOSTMOD software was applied for the calculation of the long-term financial sustainability. The results of this research are presented in the paper as the credibility scientific solutions. In addition, this research offers a practical method solution of long-term analysis and evaluation, which can be applied in solving this and similar problems, and provides an overview of the importance of the airspace control and protection, not only from military, but also, from economic aspects.

Keywords: Air Defense, Cost Analysis, KOSTMOD.

Ministry of Defence, Belgrade, Serbia; kankaras.milan@outlook.com

** Faculty of civil Aviation, Megatrend University, Belgrade, Serbia; nkapor@megatrend.edu.rs

*** Military Academy, University of Defence, Belgrade, Serbia; ivanpetrovic1977@gmail.com

**** Faculty of civil Aviation, Megatrend University, Belgrade, Serbia; asimic@megatrend.edu.rs

***** This paper is the result of the project number VA-DH/3/17-19 "Calculation of Long-term Financial Sustainability of the Duty Forces of Air Defense System of Serbian Armed Forces in Performing the Airspace Control and Protection in Peace". The project is funded by the Ministry of Defence of the Republic of Serbia. 


\section{Introduction}

One of the most important missions of the Army is state protection from external armed threats. That includes defending state territory and its airspace.

In the Republic of Serbia the airspace sovereignty protection is realized by Air Force and Air Defense (hereinafter: AFAD), but the airspace sovereignty control is an activity that is realized by AFAD in interaction with Serbia and Montenegro Air Traffic Services Agency (SMATSA Ltd.).

Basically, the airspace control and protection allows safe air traffic. Besides, it provides the revenue from the reimbursement of air navigation services provision (most of the System of Defense activities generate certain costs).

The basic research question can be formulated in the following way:

Is performing airspace control and protection long-term financially sustainable for the Republic of Serbia?

The research objective is to demonstrate that performing the airspace control and protection of the Republic of Serbia is long-term financially sustainable.

The above stated research objective gives rise to the following general hypothesis:

Ho: Performing the airspace control and protection of the Republic of Serbia is long-term financially sustainable.

\section{Research}

Airspace control and protection implies conducting many complex activities. The most important of them are:

- deterring the enemy from endangering the security of the Republic of Serbia in airspace;

- air traffic control over the territory of the Republic of Serbia, as well as over the territory of other states in accordance with international and interstate agreements;

- air surveillance and reporting on the conditions in airspace;

- protection and prevention of airspace violations of the Republic of Serbia, as well as the airspace of other states in accordance with international and interstate agreements;

- supporting civil authorities in the attempt to eliminate non-military threats to security (elimination of potential terrorist threats);

- searching and rescuing passengers and staff in the aircraft accident;

- taking anti-aircraft protection measures and procedures to reduce and eliminate consequences of operations from the airspace and

Petrović, I.; Kankaraš, M. \& Cvetković, K. (2015): Significance and Prospects of the Development of Air Defence System. Vojno delo, 67 (6), 86-98. 
- protection of the territory, population, material goods and natural resources of the Republic of Serbia from aviation threatening.

Airspace control and protection are performed by AFAD units. These units provide swift and secure flow of information about the situation in airspace and consist of: commanding, air surveillance, air protection and land protection (from air force of enemy attack) forces (Figure 1).

Figure 1. Organizational and functional structure of the forces that perform airspace control and protection ${ }^{2}$

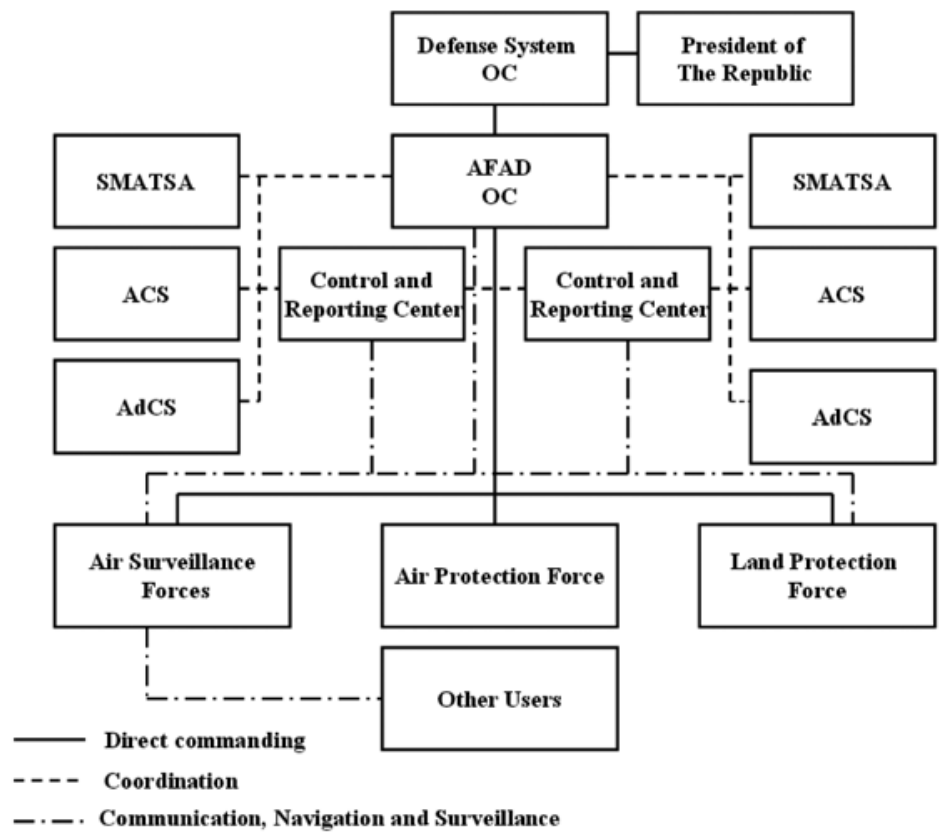

During the performance of airspace control and protection all these units and formations use services of adequate human and material resources that generate certain costs.

Human resources are the total human capacity involved in performance of this task. According to Defense Strategy of the Republic of Serbia ${ }^{3}$, material resources are natural, economic, financial, informational, technical and

2 Petrović, I.; Kankaraš, M. \& Gordić, P. (2014): Model proračuna dugoročne finansijske održivosti izvođenja operacije kontrole $i$ zaštite vazdušnog prostora [Long-term Financial Sustainability of Airspace Control and Protection Operation - Calculation Model]. Vojno delo, 2014, 66 (4), 219-226.

3 Defence Strategy of the Republic of Serbia, (2009), Belgrade. 
technological, and also include other potentials of the Republic of Serbia that are used to perform airspace control and protection.

Operating expenses (consequences of the use of movable property and buildings) and investment costs (the price of movable property and construction costs of facilities) are generated during the performance of airspace control and protection. Depending on the engagement resources, operating expenses involve: personnel, equipment and infrastructure expenses.

For the realization of cost analysis the KOSTMOD 4.0 software (hereinafter: software) is applied. The software is designed for long-term cost analysis and to the support of the Strategic Defense Planning.

Also, this software enables the identification of significant challenges that could arise in the long term perspective as a part of the Strategic Defense Planning ${ }^{4}$.

The data units (unit name, participation in operations, current status of personnel by category, current status of arms and military equipment by type of assets and the current situation by category of infrastructure facilities and their surface) and material resources (duration lifetime, the prices of new funds, escalation of investment costs and operating expenses, production year, a period between production and performing general overhaul and its price, the cost of retirement and replacement of assets) are entered into the database software.

After all the data about units and resources are entered, the initial plan of the structure force is made and eventual changes are entered, taking into consideration the planned development of units and resources. Also, the software applied entering an unlimited number of structure force plans, and each plan is an implemented simulation. The simulation is carried out for a period of 10 years or more. The conducted simulation provides the creation of a lot of different reports that show the results of simulations. General software model is shown in Figure 2.

Figure 2. General software model of KOSTMOD

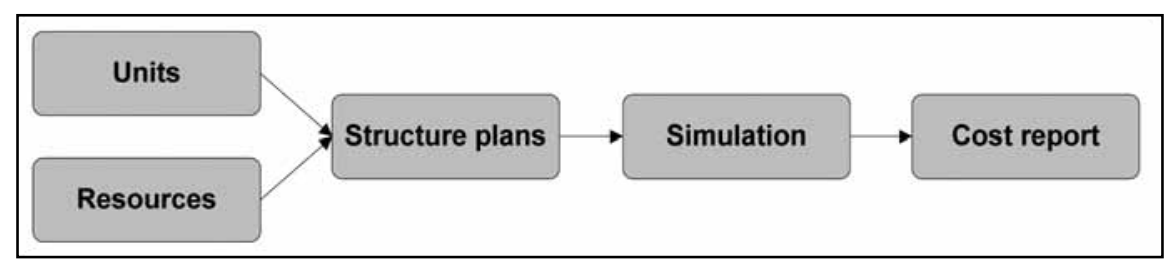

Cost analysis is determined by various factors. Operating expenses are determined by economic factors (change in the value of salary; the price of food, clothing, footwear, fuels, lubricants, ammunition, electricity, energy, water, etc.) and engagement factors (staff fluctuation, the intensity of training and engage-

Gulichsen, S. (2009): KOSTMOD 4.0 - User manual, Norwegian Defence Research Establishment (FFI). http://www.ffi.no/no/Rapporter/09-01002.pdf. 
ment, the amount of consumed food, clothing, shoes, ammunition, fuel, oil, electricity, energy, water, etc.).

The increase in operating expenses is influenced by these factors. This increase is known as the Operating Cost Escalation (hereinafter: OCE), and is expressed as a percentage of the estimated annual growth ${ }^{5}$. The purpose of the escalation of operating expenses is to calculate the personnel, equipment and infrastructure costs in the defined period. The escalation of operating expenses is calculated using the following equation (1):

$$
T=\left({ }^{G_{n^{-}} G_{1}} \sqrt{\left.\frac{V_{n}}{V_{1}}-1\right) * 100}\right.
$$

$T$-The annual growth; $G_{n}-$ The lust year; $G_{1}-$ The first year; $V_{n}-$ Value in the first year; $V_{1}$ - Value in the last year.

As well as operating expenses, investment costs are determined by economic factors. However, unlike the operating expenses, investment costs are not influenced by engagement factors ${ }^{6}$. These costs are determined by the advancement in technological solutions (technical and technological improvement is monitored between weapons systems and equipment for the same purposes, but different generations of technology).

These factors influence the increase in the cost of resources procurement, that is the Investment Cost Escalation (hereinafter: ICE), expressed as a percentage of the estimated annual increase ${ }^{7}$. The purpose of the escalation of investment costs is to assess the equipment cost and is calculated for each individual asset.

One of the challenges facing Ministry of Defense and the Army is the reduction of funds for Defense funding that is manifested by reducing the total funds for the financing of Defense and reducing the share of Gross domestic product (Figure 3).

In accordance with the development tendencies in the world, to model the forces of the System of Air Defense, it is necessary to procure 12 multi role combat airplanes; 12 helicopters; six long-range anti-aircraft missile systems; six 3 - dimensions (D); radar systems and five automation systems of command, control, communications and (computer) systems (C3 or C4 systems).

\footnotetext{
$5 \quad$ Gulichsen, S. (2009): KOSTMOD 4.0 - User manual, Norwegian Defence Research Establishment (FFI) http://www.ffi.no/no/Rapporter/09-01002.pdf.

$6 \quad$ Kirkpatrick, D. (2004): Trends in the costs of weapon systems and the consequences, Defence and Peace Economics, 15 (3), 259-279.

7 Kirkpatrick, D. (1995): The rising unit cost of Defence equipment - The reasons and result, Defence and Peace Economics, 6 (4), 263-288.
} 
Figure 3. Allocations of funds for Defense funding from the budget of the Republic of Serbia (Ministry of Finance)

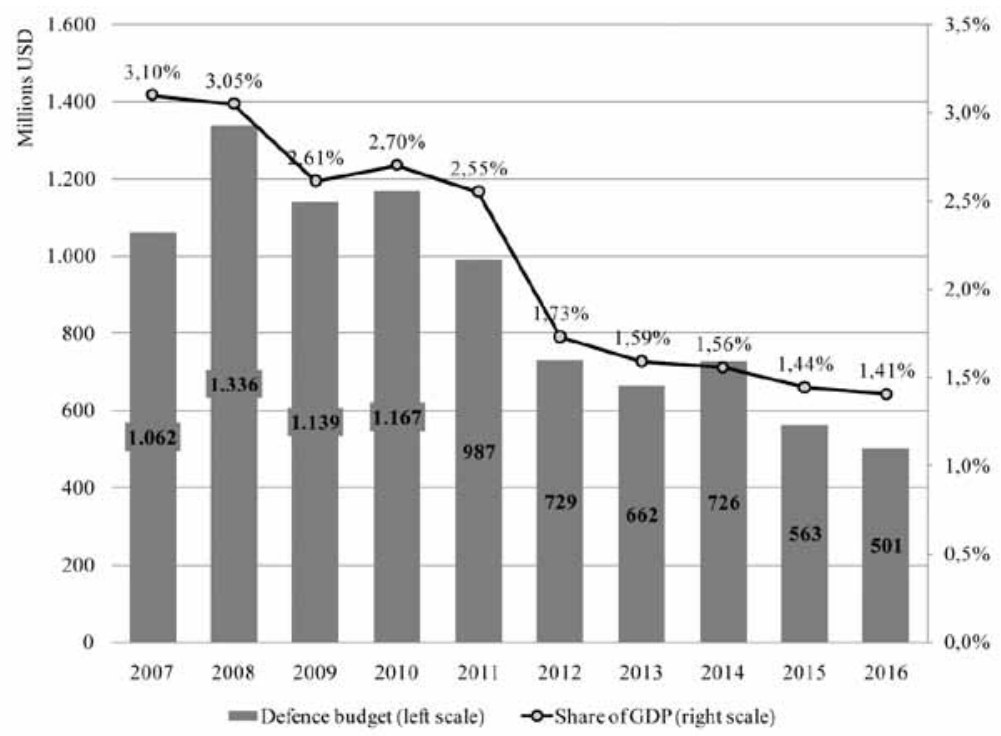

Data in accordance with aforementioned modeled structure and the costs that are based on the following data are entered into the software ${ }^{8}$ :

(1) personal annual cost per staff category, the value of which is increased by 1.43: officer US \$9,000; non-commissioned officer US \$ 6,200; professional soldier US \$ 4,700; civilian US \$ 5,900 (Ministry of Defense);

(2) the purchase price of complex combat system (Vision today): multi role combat airplane US \$55,000,000; helicopter US \$15,000,000; long-range anti-aircraft missile system US \$160,000,000; 3D radar system US \$ $50,000,000$; automation system US \$8,000,000.

To transfer Serbian dinars (RSD) into US dollars (US \$) the exchange rate on December $7^{\text {th }} 2016$ (114.9706) was applied. To calculate the costs for the period from 2018 to 2047 the OCE values are used that are shown in Table 1.

Table 1. Value data OCE

\begin{tabular}{|l|c|c|}
\hline \multicolumn{1}{|c|}{ Resource of category } & Value OCE 2018-2020 & Value OCE 2021-2047 \\
\hline Personnel & $1 \%$ & $2 \%$ \\
\hline Weapons systems and equipment & $2 \%$ & $2 \%$ \\
\hline Infrastructure & $2 \%$ & $2 \%$ \\
\hline
\end{tabular}

$8 \quad$ Ministry of Defence of Republic of Serbia. (2015): Average wages for October 2016 in the Ministry of Defence and Serbian Army (accessed December 7, 2016). 
Bearing in mind that Serbia does not produce multi role combat aircraft and long-range anti-aircraft missile system, the value of the ICE is calculated on the basis of changes in the prices of those assets (multi role combat airplane and helicopter - 6.8\%; long-range anti-aircraft missile system - 6\%).

Considering these data, an initial plan of System of Air Defense structure is made and the planned changes entered, in accordance with the dynamics of procurement of complex combat systems: multi role combat aircrafts in the period from 2018 to 2020, long-range anti-aircraft missile systems in the period from 2020 to 2023, 3D radar systems and automation systems in 2018.

In the next step the System of Air Defense structure plan is estimated for the thirty-year period (2018-2047) and a report made on the total amount of airspace control and protection costs 9 .

It is noted that there are unequal costs and expenses in two peak periods: from 2018 to 2023 (procurement of complex combat systems) and from 2033 to 2035. In the second peak period a general overhaul and procurement of antiaircraft missiles is planned.

It is also noted that there is a linear increase of operating expenses that is in accordance with the values of OCE.

\section{Results}

The simulation results and analysis are presented graphically in Figure 4.

Figure 4. Results of simulation

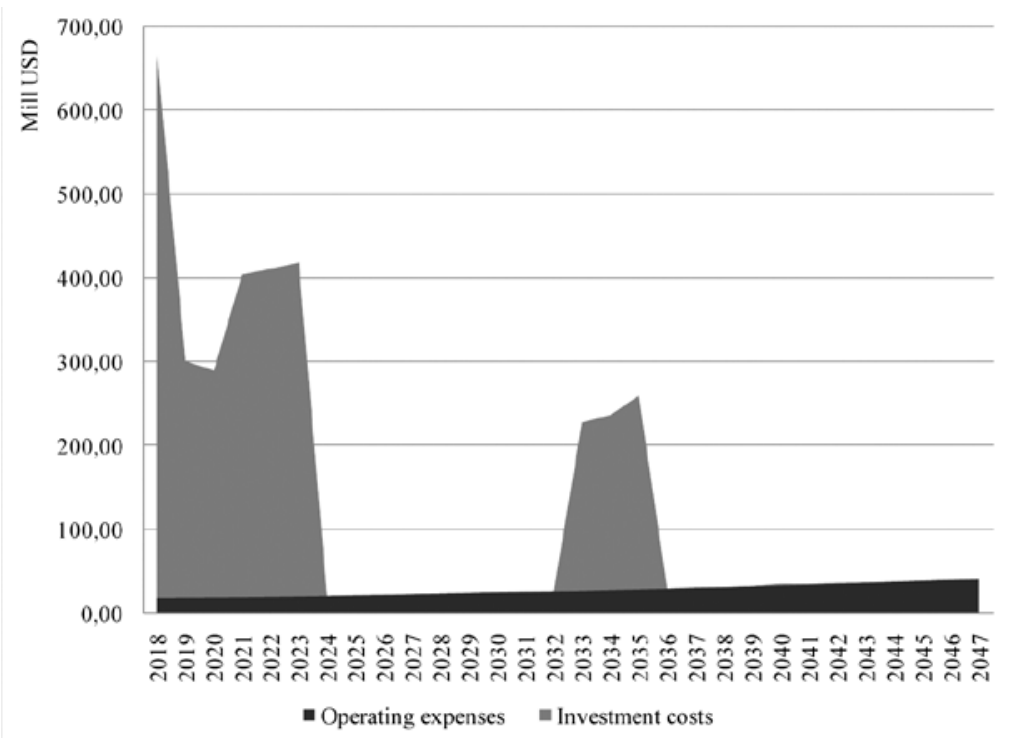

9 Ministry of Finance of Republic of Serbia. (2015): http://www.mfin.gov.rs/ (accessed December 7, 2016). 
It is concluded that performing airspace control and protection brings significant revenues from the reimbursement of air navigation services provision that is exercised by SMATSA. Since 2006, when SMATSA was established, there has been a continuous increase in the number of flights in the airspace of the Republic of Serbia, and therefore revenue growth (Table 2).

Table 2. Revenue from the reimbursement of air navigation services provision

\begin{tabular}{|c|c|c|c|}
\hline Year & Revenue (mill US\$) & Share of GDP (\%) & $\begin{array}{c}\text { Share of Defence } \\
\text { budget (\%) }\end{array}$ \\
\hline 2006. & 75.61 & $0.22 \%$ & \\
\hline 2007. & 100.79 & $0.23 \%$ & $7.12 \%$ \\
\hline 2008. & 81.87 & $0.19 \%$ & $7.54 \%$ \\
\hline 2009. & 83.28 & $0.19 \%$ & $7.19 \%$ \\
\hline 2010. & 89.21 & $0.23 \%$ & $7.14 \%$ \\
\hline 2011. & 104.70 & $0.25 \%$ & $9.04 \%$ \\
\hline 2012. & 100.01 & $0.24 \%$ & $14.36 \%$ \\
\hline 2013. & 112.20 & $0.24 \%$ & $15.11 \%$ \\
\hline 2014. & 101.58 & $0.26 \%$ & $15.45 \%$ \\
\hline 2015. & 89.90 & $0.25 \%$ & $18.03 \%$ \\
\hline
\end{tabular}

Taking into consideration data from Table 2, the revenue from the reimbursement of air navigation services provision achieved significant share of Gross domestic product of the Republic of Serbia, and in the past decade, the revenues were more than $18 \%$ of the total defense funds. The economic importance can be seen by comparing the projected costs of the airspace control and protection, and the projected revenues, which are designed using equation 1 .

The maintenance of growing trend is seen in the provided revenues that are shown in Table 3.

Table 3. Projected revenues from the reimbursement of air navigation services provision for assimilated period

\begin{tabular}{|c|c|c|c|c|c|}
\hline Year & $\begin{array}{c}\text { Estimated } \\
\text { revenue } \\
\text { (Mill USD) }\end{array}$ & Year & $\begin{array}{c}\text { Estimated } \\
\text { revenue } \\
\text { (Mill USD) }\end{array}$ & Year & $\begin{array}{c}\text { Estimated } \\
\text { revenue } \\
\text { (Mill USD) }\end{array}$ \\
\hline 2018. & 95,24 & $\mathbf{2 0 2 8}$. & 115,45 & 2038. & 139,93 \\
\hline $\mathbf{2 0 1 9 .}$ & 97,09 & $\mathbf{2 0 2 9}$. & 117,69 & 2039. & 142,65 \\
\hline $\mathbf{2 0 2 0 .}$ & 98,98 & $\mathbf{2 0 3 0}$. & 119,97 & 2040. & 145,42 \\
\hline
\end{tabular}




\begin{tabular}{|l|l|l|l|l|l|}
\hline $\mathbf{2 0 2 1 .}$ & 100,90 & $\mathbf{2 0 3 1}$ & 122,30 & 2041. & 148,24 \\
\hline $\mathbf{2 0 2 2}$. & 102,86 & 2032. & 124,68 & 2042. & 151,12 \\
\hline $\mathbf{2 0 2 3 .}$ & 104,86 & 2033. & 127,10 & 2043. & 154,06 \\
\hline $\mathbf{2 0 2 4}$. & 106,90 & 2034. & 129,57 & 2044. & 157,05 \\
\hline $\mathbf{2 0 2 5 .}$ & 108,97 & 2035. & 132,08 & 2045. & 160,10 \\
\hline $\mathbf{2 0 2 6 .}$ & 111,09 & 2036. & 134,65 & 2046. & 163,21 \\
\hline $\mathbf{2 0 2 7}$. & 113,25 & 2037. & 137,26 & 2047. & 166,38 \\
\hline
\end{tabular}

By comparing the projected costs and revenues it is noted that the revenues extremely exceed the operating expenses. However, in the peak period from 2018 to 2023, the investment costs exceed revenues, but equal distribution of the investment costs for all analyzed periods shows that revenues were above costs and expenses. The relationship between the costs and expenses, and revenues is shown in Figure 5.

Figure 5. Comparison of projected costs and revenues

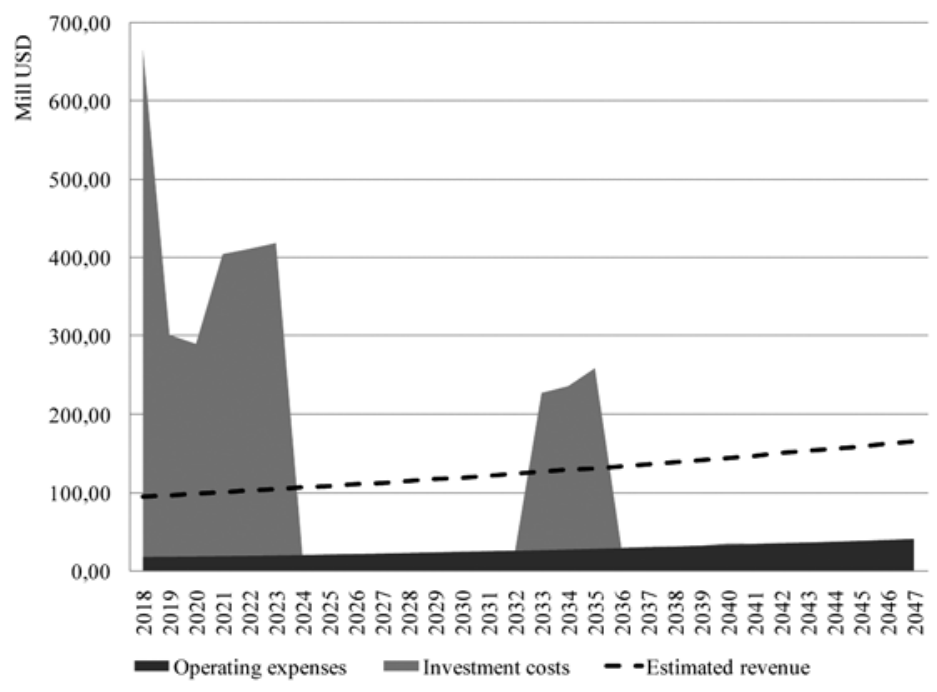

\section{Discussion}

Researching an economic aspect of the performance of airspace control and protection is introduced only by a few studies.

The liberalization trend in performing air traffic tasks in modern macroeconomic business environment is researched by Grancay and Szirokova ${ }^{10}$. Development of the forecasting methodology for the operation and maintenance

10 Grancay, M. \&Szirokova, N. (2014): Liberalism in Foreign Trade versus Liberalism in Air Transportation-Is there a Link?.Panoeconomicus, 6, 709 - 721. 
costs for all military equipment is researched by Sokry ${ }^{11}$. This methodology can be used for researching some aspects of the performance of airspace control and protection task.

In addition, Sokry ${ }^{12}$ researched an optimal life cycle of military aircraft from economical point of view that can be used for the calculation of investment costs and operating expenses not only for military aircrafts, but also for anti-aircraft missile and $3 \mathrm{D}$ radar system.

It also researched and introduced a model to calculate long-term financial sustainability of the airspace control and protection operation, which can be applied in research of the causal relationship between requirements and needs during surveillance of airspace traffic ${ }^{13}$.

There are a lot of scientific studies that researched possible methods of improving air force organization and operations that perform airspace control and protection in peace, in case of potential appearance of asymmetric airspace threats. For example ${ }^{14}$, studies have been conducted about the possibility of improving effectiveness, efficiency, flexibility and interoperability of Serbian Air Defense System during the performance of air traffic management tasks in the Republic of Serbia and the region ${ }^{15}$. The importance of the anti-aircraft missile units in improving the safety of the Republic of Serbia airspace was examined, as well as the economic viability of the performance of the airspace protection exclusively by these units. The number of these studies has been increased since September 11, 2001, after the airspace terrorist attack in the United States of America (case "Renegade"). However, despite these studies, economic aspect was not completely identified according to available and relevant data. In the example of the Republic of Serbia, the conclusions of the analysis of the costs and expenses and revenues from the reimbursement of air navigation services provision are the following:

- the performance of the airspace control and protection of the Republic of Serbia is long-term financially sustainable;

11 Sokry, A. (2014): Life Cycle Costing of Military Equipment, International Conference of Control, Dynamic Systems, and Robotics. Ottawa, Ontario, Canada, Paper No. 45, 1-9.

12 Sokry, A. (2011): Optimal replacement of military aircraft: an economic approach, Defence and PeaceEconomics, 22(6), 645-653.

13 Petrović, I.; Kankaraš, M. \&Gordić, P. (2014): Model proračuna dugoročne finansijske održivosti izvođenja operacije kontrole i zaštite vazdušnog prostora [Long-term Financial Sustainability of Airspace Control and Protection Operation - CalculationModel]. Vojnodelo, 2014, 66 (4), 219-226.

14 Petrović, I.; Kankaraš, M. \&Cvetković, K. (2015): Significance and Prospects of the Development of Air Defence System, Vojnodelo, 67 (6), 86-98

15 Gordic, M.; Petrovic, I. \& Cvetkovic, K. (2014): Uloga raketnihjedinicazaprotivvazduhoplovna dejstva u operaciji kontrole $i$ zastite vazdušnog prostora [The Roleof Air Defense Missile Units in the Air SpaceControl and Protection], Vojno delo 66 (2), 210 - 231. 
- in the procurement of new complex weapons systems and equipment, it is possible to finance the long-term loans that could be repaid from revenues from the reimbursement of air navigation services provision.

\section{Conclusion}

In the society there is a stereotype that the Army, and therefore AFAD, represents a spendthrift organization. However, in addition to costs and expenses, the Army has a significant potential to make revenues. Eligibility of the Army to earn money is shown in the case of AFAD units that perform airspace control and protection.

On the basis of the analysis of the costs and expenses that are generated by the engagement of AFAD resources and projected revenues from the reimbursement of air navigation services provision for a period of 30 years, it can be concluded that the performance of airspace control and protection of the Republic of Serbia is long-term financially sustainable, which has confirmed the general hypothesis of this research.

\section{Literature}

- Defence Strategy of the Republic of Serbia. (2009): Belgrade.

- Gordic, M.; Petrovic, I. \& Cvetkovic, K. (2014): Uloga raketnih jedinica za protivvazduhoplovna dejstva u operaciji kontrole $i$ zastite vazdušnog prostora [The Roleof Air Defense Missile Units in the Air Space Control and Protection]. Vojno delo 66 (2), 210 - 231.

- Grancay, M. \& Szirokova, N. (2014): Liberalism in Foreign Trade versus Liberalism in Air Transportation - Is there a Link? Panoeconomicus, 6, 709 - 721.

- Gulichsen, S. (2009). KOSTMOD 4.0 - User manual. Norwegian Defence Research Establishment (FFI). http://www.ffi.no/no/Rapporter/09-01002.pdf.

- Kirkpatrick, D. (2004): Trends in the costs of weapon systems and the consequences, Defence and Peace Economics, 15 (3), 259-279.

- Kirkpatrick, D. (1995): The rising unit cost of Defence equipment - The reasons and results, Defence and Peace Economics, 6 (4), 263-288

- Ministry of Defence of Republic of Serbia. (2015): Average wages for October 2016 in the Ministry of Defence and Serbian Army (accessed December 7, 2016)

- Ministry of Finance of Republic of Serbia. (2015): http://www.mfin.gov.rs/ (accessed December 7, 2016).

- Petrović, I.; Kankaraš, M. \& Cvetković, K. (2015): Significance and Prospects of the Development of Air Defence System, Vojno delo, 67 (6), 86-98. 
- Petrović, I.; Kankaraš, M. \& Gordić, P. (2014): Model proračuna dugoročne finansijske održivosti izvođenja operacije kontrole i zaštite vazdušnog prostora [Long-term Financial Sustainability of Airspace Control and Protection Operation - Calculation Model]. Vojno delo, 2014, 66 (4), 219-226.

- Sokry, A. (2014): Life Cycle Costing of Military Equipment, International Conference of Control, Dynamic Systems, and Robotics, Ottawa, Ontario, Canada, Paper No.45, 1-9.

- Sokry, A. (Forthcoming). A Golden Rule of Discounting for Civilian and Military Projects. DRDC CORA, Technical Memorandum, Ottawa, Canada.

- Sokry, A. (2011): Optimal replacement of military aircraft: an economic approach, Defence and Peace Economics, 22(6), 645-653.

- Vizija danas. (2015): http://www.vizijadanas.com/svet/mig_35.html (accessed mart 5, 2015).

- http://mod.gov.rs/multimedia/file/staticki_sadrzaj/informator/2016/novembar/plate_novembar_2016_cir.pdf. 


\section{EKONOMSKI ASPEKTI KONTROLE I ZAŠTITE VAZDUŠNOG PROSTORA}

Kontrola i zaštita vazdušnog prostora značajna je za sve države sa bezbednosnih, političkih, ekonomskih i drugih aspekata. Međutim, kontrola i zaštita vazdušnog prostora zahteva angažovanje tehnologije i ljudi čije prisustvo generiše određene troškove. $U$ ovom radu su prikazani rezultati istraživanja dugoročne finansijske održivosti kontrole i zaštite vazdušnog prostora na primeru Republike Srbije. Analiza troškova i dugoročna finansijska održivost izvršenja zadatka zaštite vazdušnog prostora, sprovedena je primenom softvera KOSTMOD, primenjujući podatke iz otvorenih izvora. Rešenja prikazana u radu, kao i izneti stavovi, predstavljaju viziju autorovog rada. Rad nudi praktična rešenja načina sprovođenja dugoročnih analiza i procena, te na osnovu tih rešenja može biti primenjen, kako za rešavanje ovog zadatka, tako i za rešavanje njemu sličnih.

Dakle, ovaj rad pruža potrebna rešenja za kontrolu i zaštitu vazdušnog prostora, ne samo sa vojnog, nego i sa ekonomskog aspekta.

Ključne reči: Vazdušna odbrana, analiza troškova, KOSTMOD. 